NASA/TM-1998-208481

High Stability Engine Control (HISTEC) Flight Test Results

Robert D. Southwick, George W. Gallops, Laura J. Kerr, Robert P. Kielb, and Mark G. Welsh Pratt \& Whitney, West Palm Beach, Florida

John C. DeLaat

Lewis Research Center, Cleveland, Ohio

John S. Orme

Dryden Flight Research Center, Edwards, California 
Since its founding, NASA has been dedicated to the advancement of aeronautics and space science. The NASA Scientific and Technical Information (STI) Program Office plays a key part in helping NASA maintain this important role.

The NASA STI Program Office is operated by Langley Research Center, the Lead Center for NASA's scientific and technical information. The NASA STI Program Office provides access to the NASA STI Database, the largest collection of aeronautical and space science STI in the world. The Program Office is also NASA's institutional mechanism for disseminating the results of its research and development activities. These results are published by NASA in the NASA STI Report Series, which includes the following report types:

- TECHNICAL PUBLICATION. Reports of completed research or a major significant phase of research that present the results of NASA programs and include extensive data or theoretical analysis. Includes compilations of significant scientific and technical data and information deemed to be of continuing reference value. NASA's counterpart of peerreviewed formal professional papers but has less stringent limitations on manuscript length and extent of graphic presentations.

- TECHNICAL MEMORANDUM. Scientific and technical findings that are preliminary or of specialized interest, e.g., quick release reports, working papers, and bibliographies that contain minimal annotation. Does not contain extensive analysis.

- CONTRACTOR REPORT. Scientific and technical findings by NASA-sponsored contractors and grantees.
- CONFERENCE PUBLICATION. Collected papers from scientific and technical conferences, symposia, seminars, or other meetings sponsored or cosponsored by NASA.

- SPECIAL PUBLICATION. Scientific, technical, or historical information from NASA programs, projects, and missions, often concerned with subjects having substantial public interest.

- TECHNICAL TRANSLATION. Englishlanguage translations of foreign scientific and technical material pertinent to NASA's mission.

Specialized services that complement the STI Program Office's diverse offerings include creating custom thesauri, building customized data bases, organizing and publishing research results ... even providing videos.

For more information about the NASA STI Program Office, see the following:

- Access the NASA STI Program Home Page at http://www.sti.nasa.gov

- E-mail your question via the Internet to help@sti.nasa.gov

- Fax your question to the NASA Access Help Desk at (301) 621-0134

- Telephone the NASA Access Help Desk at (301) 621-0390

- Write to:

NASA Access Help Desk

NASA Center for AeroSpace Information 7121 Standard Drive

Hanover, MD 21076 
NASA/TM-1998-208481

AIAA-98-3757

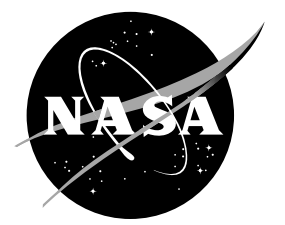

\section{High Stability Engine Control (HISTEC) Flight Test Results}

Robert D. Southwick, George W. Gallops, Laura J. Kerr, Robert P. Kielb, and Mark G. Welsh Pratt \& Whitney, West Palm Beach, Florida

John C. DeLaat

Lewis Research Center, Cleveland, Ohio

John S. Orme

Dryden Flight Research Center, Edwards, California

Prepared for the

34th Joint Propulsion Conference

cosponsored by AIAA, ASME, SAE, and ASEE

Cleveland, Ohio, July 12-15, 1998

National Aeronautics and

Space Administration

Lewis Research Center 
Trade names or manufacturers' names are used in this report for identification only. This usage does not constitute an official endorsement, either expressed or implied, by the National Aeronautics and Space Administration.

Available from

NASA Center for Aerospace Information 7121 Standard Drive

Hanover, MD 21076

Price Code: A03
National Technical Information Service 5287 Port Royal Road Springfield, VA 22100 Price Code: A03 


\title{
HIGH STABILITY ENGINE CONTROL (HISTEC) FLIGHT TEST RESULTS
}

\author{
R. D. Southwick, G. W. Gallops, L. J. Kerr, R. P. Kielb, and M. G. Welsh \\ Pratt \& Whitney \\ West Palm Beach, FL 33410-9600 \\ J. C. DeLaat \\ NASA Lewis Research Center \\ Cleveland, $\mathrm{OH}$ \\ J. S. Orme \\ NASA Dryden Flight Research Center \\ Edwards, CA
}

\begin{abstract}
The High Stability Engine Control (HISTEC) Program, managed and funded by the NASA Lewis Research Center, is a cooperative effort between NASA and Pratt \& Whitney $(\mathrm{P} \& \mathrm{~W})$. The program objective is to develop and flight demonstrate an advanced highstability integrated engine control system that uses realtime, measurement-based estimation of inlet pressure distortion to enhance engine stability. Flight testing was performed using the NASA Advanced Controls Technologies for Integrated Vehicles (ACTIVE) F-15 aircraft at the NASA Dryden Flight Research Center. The flight test configuration, details of the research objectives, and the flight test matrix to achieve those objectives are presented. Flight test results are discussed that show the design approach can accurately estimate distortion and perform real-time control actions for engine accommodation.
\end{abstract}

\section{INTRODUCTION}

Future commercial and military aircraft turbine engines must successfully accommodate expected increased levels of steady-state and dynamic inlet distortion. Advanced tactical aircraft are likely to use low observable inlets and, possibly, thrust vectoring for enhanced aircraft maneuverability. As a result, engines will probably experience higher levels of distortion than currently encountered in operational aircraft. Also, the mixed-compression inlets needed for the High Speed Civil Transport (HSCT) are likely to encounter disturbances similar to those seen by tactical aircraft, in addition to planar pulse, inlet buzz, and high distortion levels at low flight speed and off-design operation.

In conjunction with accommodating increased levels of distortion, Pratt \& Whitney (P\&W) has been pursuing controls research to help reduce compression system design stall margin requirements from current levels. The reduced margin requirements could be traded off during engine design for increased engine performance and decreased weight. Some of this research has been demonstrated through engine testing on Joint Technology Demonstrator Engines (JTDE) under Department of Defense sponsorship. Studies conducted under P\&W Independent Research \& Development (IR\&D) showed potential benefit for inflight sensing of inlet distortion to enhance engine stability management, resulting in further improvements in engine performance.

The High Stability Engine Control (HISTEC) Program, managed and funded by NASA Lewis Research Center, is a cooperative effort between NASA and P\&W. Flight testing was accomplished by the NASA Dryden Flight Research Center on a highly modified F-15 aircraft provided by the U.S. Air Force. Boeing St. Louis supported HISTEC integration on the F-15 flight test aircraft. The primary objective of the program is to develop and flight demonstrate an advanced high stability integrated engine control system that uses realtime, measurement-based estimation of inlet pressure distortion to enhance engine stability. A secondary objective is to enhance the inflight dynamic distortion database. The three-phase HISTEC Program was initiated in 1993: Phase I - Algorithm Development; Phase II - Concept Validation and System Development; Phase III — Engine Test and Flight Demonstration. ${ }^{123}$

After the distortion estimation algorithms were developed in Phase I, system verification using detailed simulations was conducted in a software environment. The system modeled included the distortion estimation system (DES) algorithms, dynamic inlet pressure inputs, ACTIVE F-15 flight control bus, and F100-PW-229 engine with HISTEC stability management control. Test points included planned flight conditions over the HISTEC flight envelope. The model was modified in the latter part of Phase II to include the flight hardware integrated with a real-time simulation of the engine at $\mathrm{P} \& \mathrm{~W}$, and at Boeing St. Louis.

Flight test was accomplished on the NASA ACTIVE F-15 aircraft. Prior to flight test, P\&W conducted two ground engine tests to further prove out the 
system. This extensive checkout of the HISTEC system was instrumental in the successful flight test at NASA Dryden during the summer of 1997.

\section{HISTEC APPROACH}

The HISTEC concept quantifies inlet distortion characteristics and their impact on compression system stability through the DES. The DES uses six inputs of high response static pressure measurements near the fan face at six locations, five outer diameter (OD) and one inner diameter (ID). The HISTEC implementation adjusts the engine operating point based on distortion inputs from the DES to maintain sufficient stall margin through stability management control (SMC) logic.

The HISTEC approach to meet the high stability engine control requirements is illustrated in Figure 1. Pratt \& Whitney developed a practical implementation for sensing inlet pressure distortion and a unique algorithm concept for determining distortion pattern characteristics and intensities based on inlet measurements. ${ }^{4}$ The DES is used in conjunction with advanced SMC algorithms designed for the F100-PW-229 improved digital electronic engine control (IDEEC). Highresponse pressure measurements at the engine face are used as inputs to the DES to classify the inlet distortion pattern and debit the stall line through the use of sensitivities derived in the frequency domain. The primary outputs of the DES are trims, representing fan and compressor stall line losses, that are sent to the IDEEC as inputs to the onboard stability audit.
To improve response to rapid aircraft maneuvers in a timely fashion, the DES incorporates angle-of-attack $(\alpha)$ and angle-of-sideslip $(\beta)$ predictor algorithms supplied by Boeing St. Louis. The predictor algorithms use aircraft flight control inputs to account for the half-second delay in executing the DES algorithm.

\section{Distortion Estimation System Concept}

In Phases I and IIA of the HISTEC Program, P\&W developed a real-time distortion estimation algorithm following the basic concepts of traditional stability audit methodology as represented in Society of Automotive Engineers Aerospace Recommended Practice (SAE ARP) 1420 Gas Turbine Engine Inlet Flow Distortion Guidelines. ${ }^{5}$ This methodology consists of standards for measurement, pattern classification, and computation of stability debits (Figure 2). This methodology depends on a key assumption - the superposition of individual circumferential, radial, and planar dynamic distortion stability debits.

The basic structure of the algorithm is consistent with traditional inlet distortion analysis methodology (Figure 3). The instantaneous total pressure pattern derived from inlet pressure sensors is categorized according to three descriptors: circumferential and radial descriptors similar to ARP 1420, and a planar dynamic descriptor (described in SAE Aerospace Resource Document [ARD] 50026 A Current Assessment of Planar Waves). ${ }^{6}$ The circumferential descriptor is obtained by spatial discrete Fourier transform (DFT) of the OD measurements. Only circumferential Modes 1 and 2 are calculated for the ACTIVE F-15 implementa-

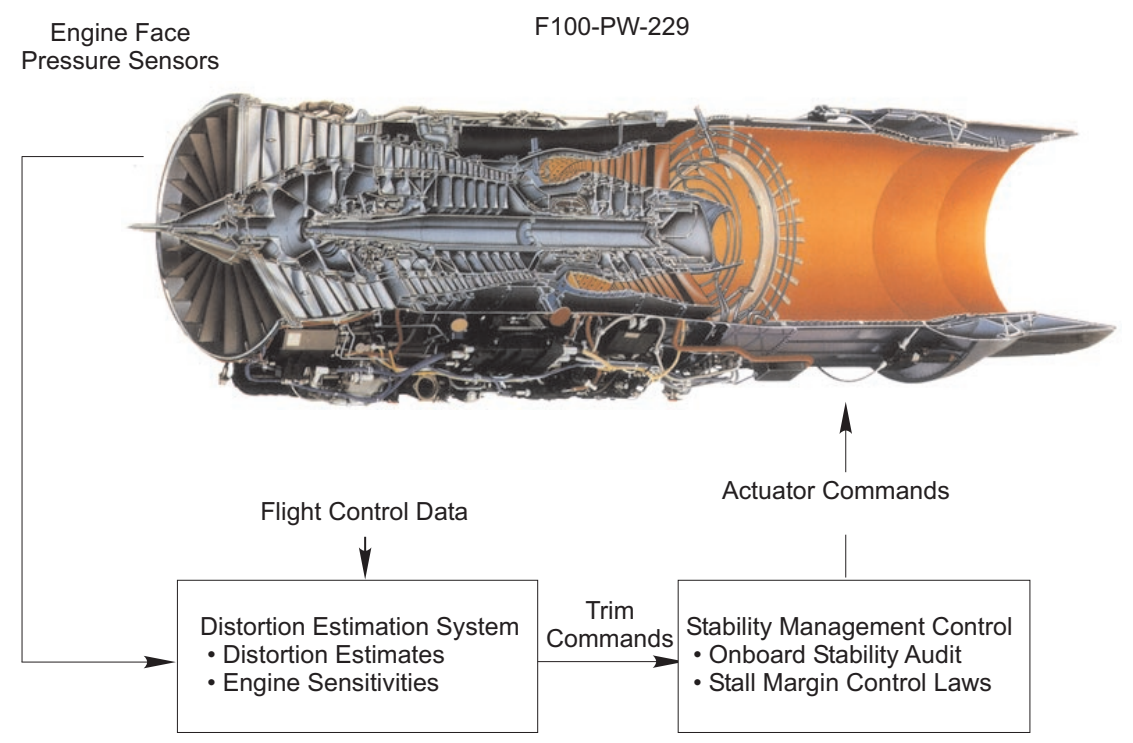

Figure 1. HISTEC Control Overview 


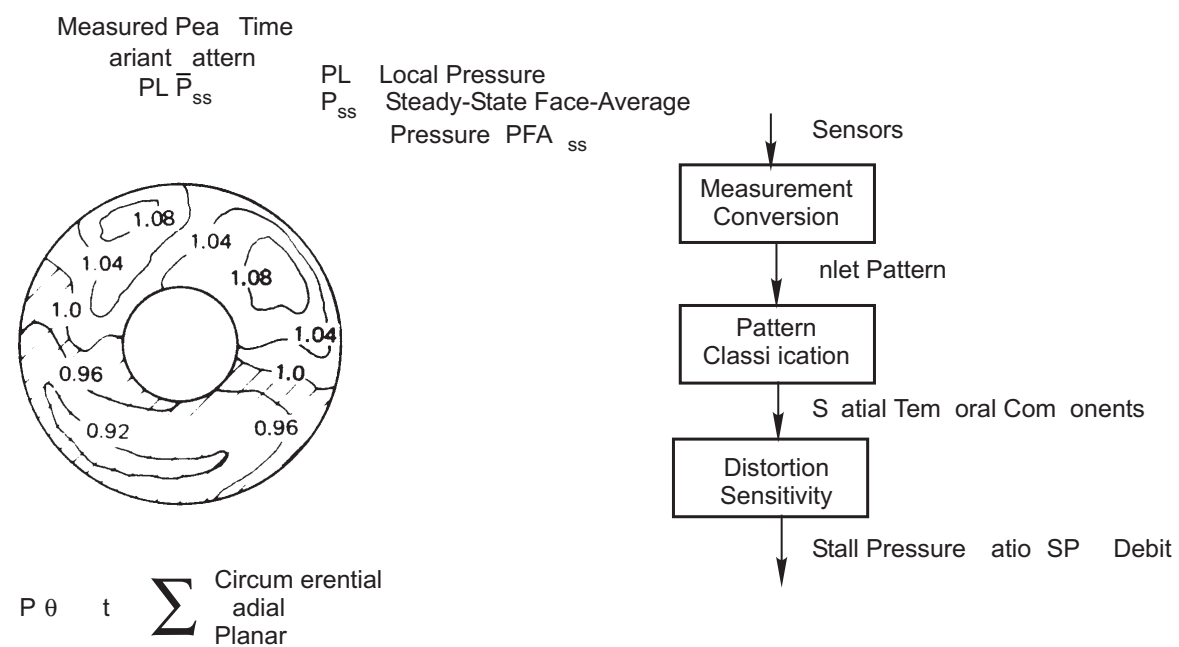

Figure 2. Traditional Audit Methodology

tion. The temporal Fast Fourier Transform (FFT) of the DFT circumferential components yields circumferential dynamic distortion intensity. The radial and planar distortion intensities and the instantaneous average pressure at the engine inlet plane are similarly calculated, using a discrete sine transform (DST) of the mean of the OD and ID measurements. Only radial Modes 1 and 3 are calculated for the ACTIVE F-15 implementation.
Fourier analysis is an efficient means of implementing ARP 1420 methodology and lends itself to digital signal processing techniques. The impact on fan and compressor stall pressure ratio from inlet distortion is determined by applying frequency-dependent sensitivities to dynamic distortion components. These are defined using a two-dimensional stability model similar to those described in References 7 and 8. Note that

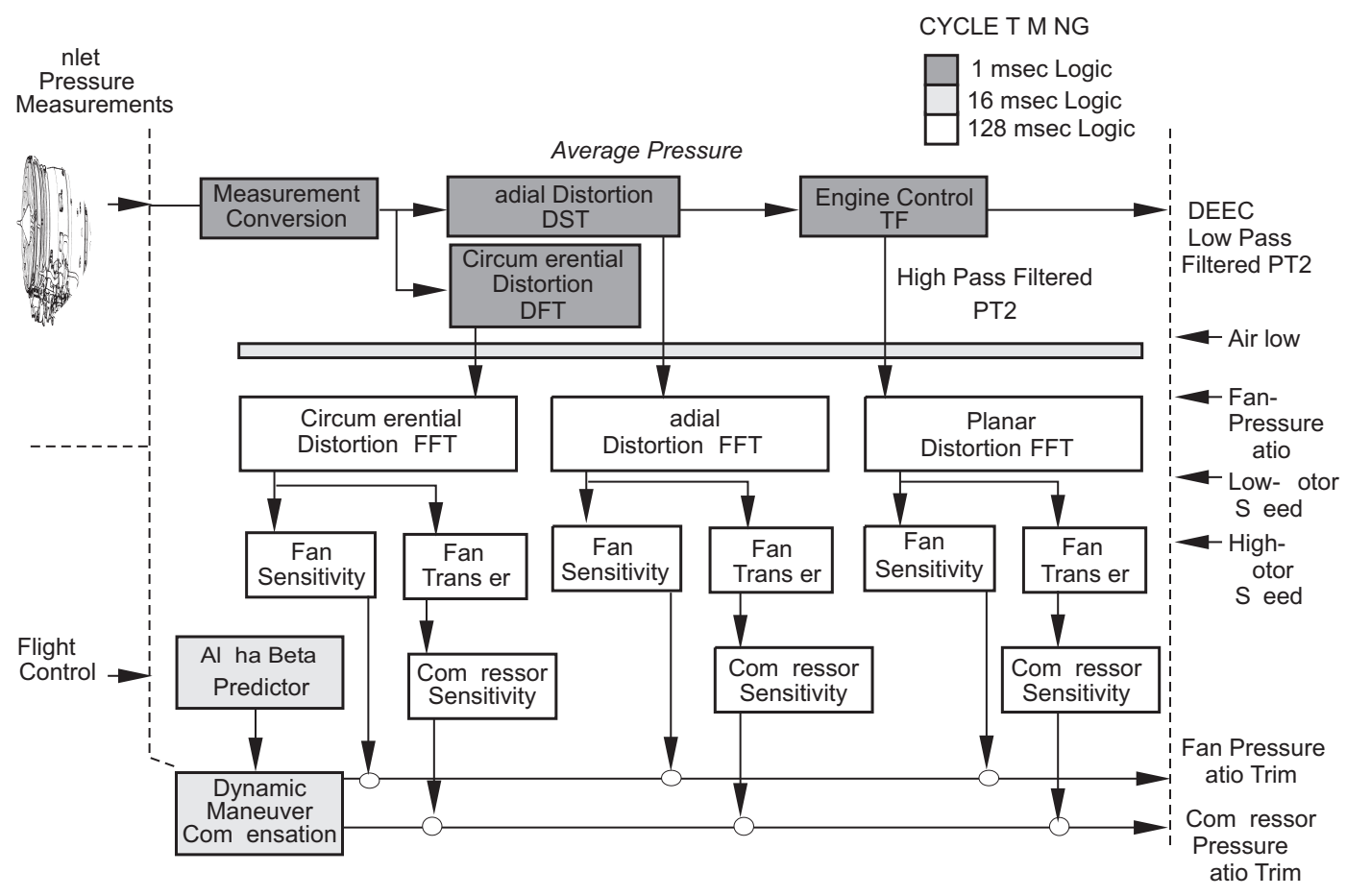

Figure 3. DES Algorithm Overview 
compressor inlet distortion is not directly measured by the DES. It is determined by applying a fan distortion transfer function to the inlet distortion components.

Because of computational delays and the limited response of the engine and control with this particular configuration, dynamic compensation must be applied to fan and compressor limit trims to accommodate rapid aircraft maneuvers. Transient lead functions are based on predicted (approximately 0.5 second lead time) values of $\alpha$ and $\beta$.

\section{Stability Management Control}

The HISTEC SMC algorithms were successfully implemented into a production F100-PW-229 engine control that met requirements for integration with the ACTIVE F-15 aircraft. ${ }^{9}$ The SMC algorithms consisted of an onboard real-time stability audit for the fan and compressor that quantifies all destabilizing effects on stall margin, including the effects of inlet distortion determined by the DES. The SMC algorithms dynamically adjust the fan and compressor operating lines (oplines) in response to changes in instantaneous stall margin remaining from the audit.

Real-time stability audits implemented for HISTEC are based on stability audit methodology used for all $\mathrm{P} \& \mathrm{~W}$ commercial and military engines. The methodology considers all destabilizing influences for the compression system including random variations. The HISTEC stability audit algorithms provide the same type of stability evaluation in real time as is traditionally performed off-line. Some inputs to the off-line stability audit include additional measurements from engine development instrumentation not available to the
IDEEC. These additional data are calculated by the IDEEC.

Because the F100-PW-229 engine is designed with enough stall margin to accommodate the worst stability threats anywhere in the F-15 operational flight envelope over the life of the engine, a means was devised for HISTEC to demonstrate the actions of the SMC algorithms. The objective was to functionally demonstrate the effectiveness of the algorithms in an aggressive but safe manner, and with a production-like implementation. This was accomplished by incorporating a simulated stability audit limit that allowed HISTEC to operate away from the actual engine stall line, yet permitted variable engine operating margins. This simulated audit limit represents the stability limit of a fan or compressor component with reduced design stall margin. The flexibility of the digital engine control allowed the simulated stability limit, referred to as the technology bias, to be readily changed between flights as desired. All compression system destabilizing influences, including the inlet distortion effects from the DES, are debited from the simulated stability limit to arrive at the stall margin remaining used by the SMC.

\section{FLIGHT TEST PROGRAM}

The flight test program was designed to methodically evaluate the HISTEC approach to high stability engine control and to provide a significant amount of high-quality inflight dynamic inlet distortion data. Together, P\&W, NASA Lewis, and NASA Dryden defined a comprehensive test matrix that included 106 flight test points. Figure 4 shows the HISTEC flight envelope and flight conditions, which included steady

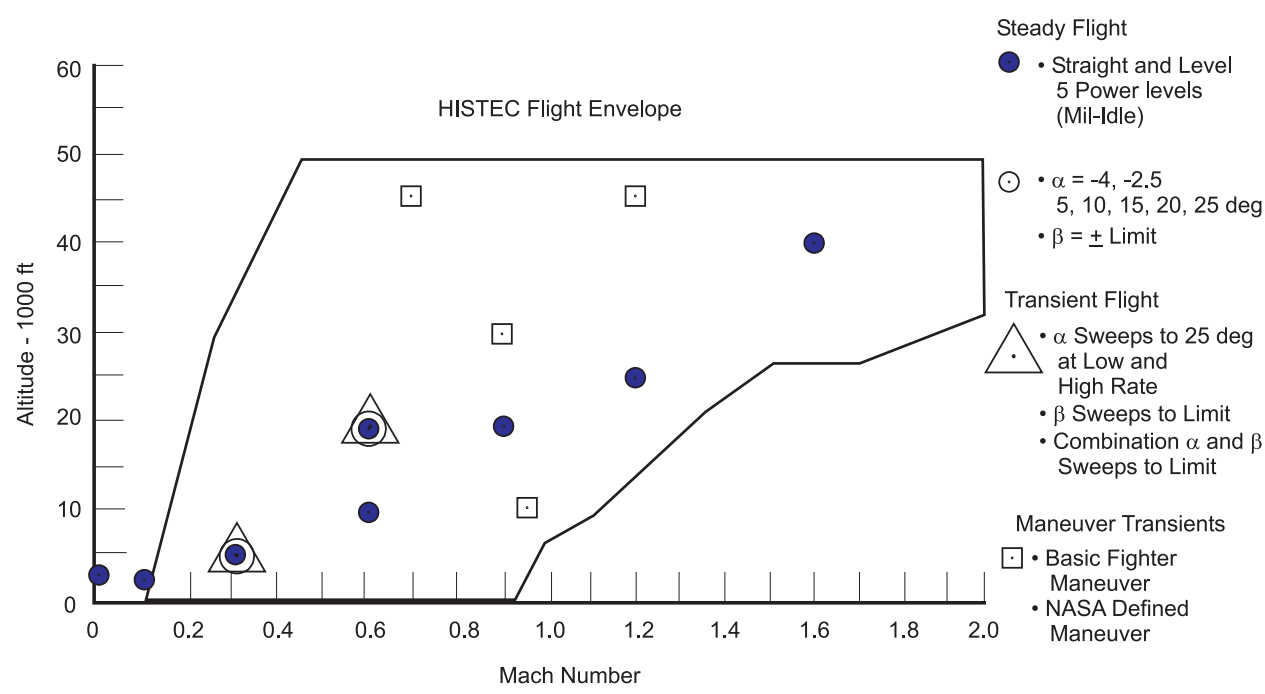

Figure 4. HISTEC Flight Envelope 
flight and aggressive maneuvers up to the aircraft $\alpha, \beta$, and $g$ limits. NASA and P\&W established success criteria for HISTEC DES accuracy at specific flight conditions. The HISTEC goal was to provide a real-time estimate of stall margin loss (SML) due to inlet distortion to within \pm 2.5 percent of the SML calculated offline using extensive inlet research instrumentation and ARP 1420 methodology.

The HISTEC flight test matrix was accomplished in two parts. Part 1 of the flight test included an extensive matrix of test points to obtain the distortion database and determine the ability of the DES to accurately estimate SML due to inlet distortion. Although the SMC laws within the engine control were executed for evaluation purposes, the control did not send trim data to the engine for stability accommodation during Part 1. This is referred to as open-loop operation. At the conclusion of Part 1, flight test data analysis was performed to determine the need to fine-tune the HISTEC algorithms prior to proceeding with Part 2 of flight test. Part 2 of the HISTEC flight test program focused on closed-loop operation where the control modified engine operation to maintain engine stability based on inputs from the DES.

\section{Flight Test Configuration}

The HISTEC flight tests were conducted at the NASA Dryden Flight Research Center at Edwards Air Force Base, California on the NASA ACTIVE F-15 aircraft (Figure 5). Although the aircraft was equipped with thrust vectoring nozzles, they were not used during HISTEC testing due to data bus constraints in accommodating the HISTEC control hardware.

The HISTEC instrumented inlet case is a modified production F100-PW-229 inlet case that incorporates

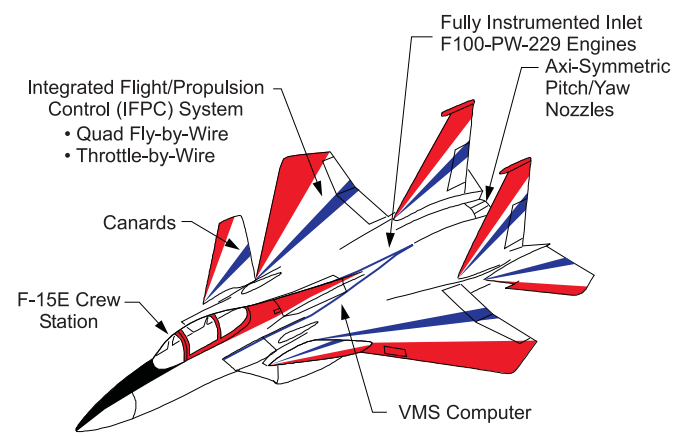

Figure 5. ACTIVE Testbed

HISTEC-specific instrumentation. The HISTEC DES receives six high response static pressure inputs: five outer diameter (OD) pressure measurements and the (electrical) average of five inner diameter (ID) pressure measurements. Static pressure taps are located between struts on the OD and ID inlet case shrouds (Figure 6).

To evaluate the DES and augment the distortion database, a full complement of research instrumentation (for reference only) was installed in the engine inlet case. An array of 35 high-response total pressure sensors was installed in the leading edges (LEs) of the inlet struts. The strut LE pressure sensors are located on 7 inlet case struts, 5 sensors per strut, distributed radially on each strut by equal flowpath area. A total temperature sensor, used for temperature compensation, was installed approximately mid-span on each instrumented inlet strut LE. Nine additional OD pressure sensors (five adjacent to the DES sensors for data recording) were added for a more complete circumferential mapping of inlet profiles.

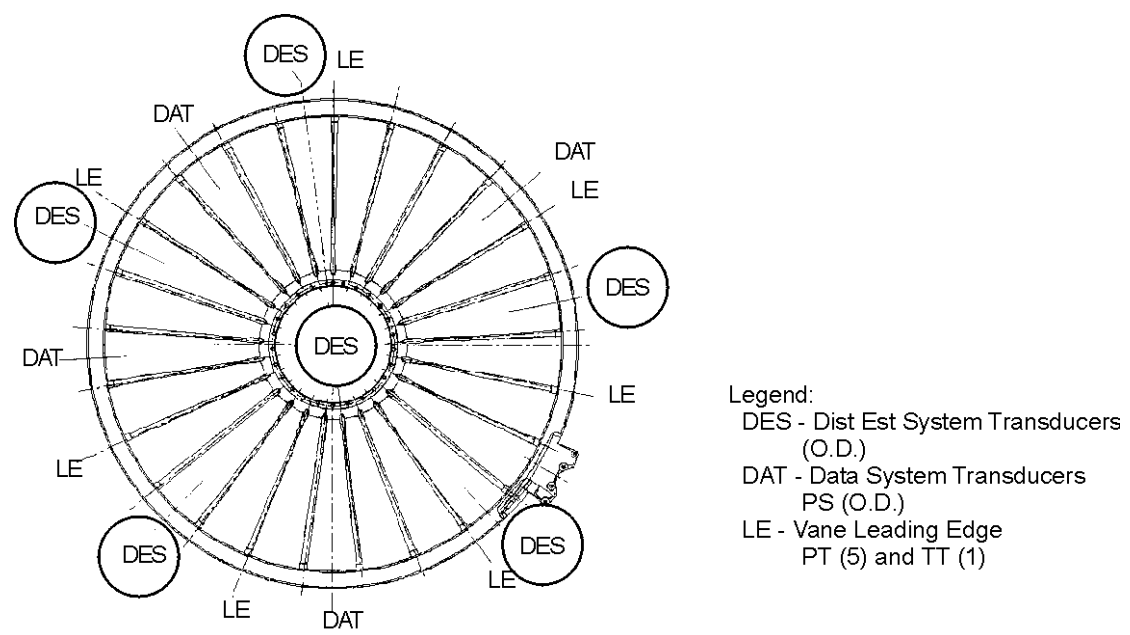

Figure 6. HISTEC Instrumented Inlet Case 
The DES algorithms were incorporated in a highspeed processor that calculated real-time distortion characteristics and intensities from the inlet pressure measurements. For HISTEC, the DES computer (Figure 7) was aircraft-mounted and communicated with the engine control through the aircraft flight control 1553 data communications bus. To accommodate the existing bus architecture, the DES was installed in place of Channel B of the Vehicle Management System Computer (VMSC). This required additional software in the DES to emulate the VMSC Channel B to prevent wraparound failures with the aircraft flight control. Modifications to the bus architecture are shown in Figure 8.

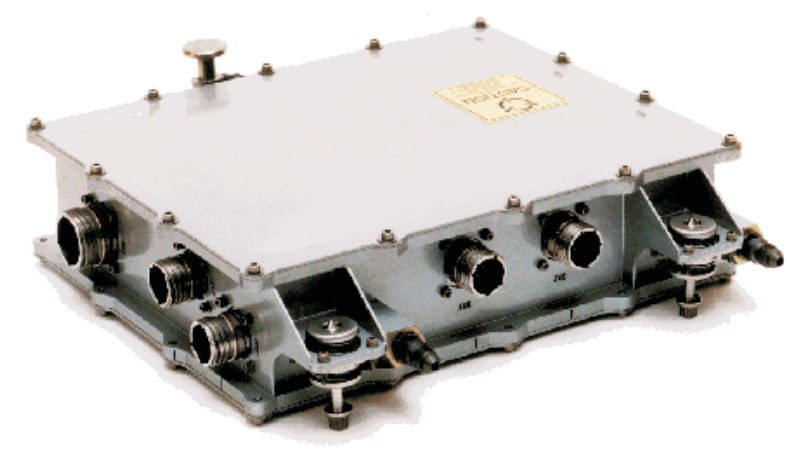

Figure 7. DES Computer

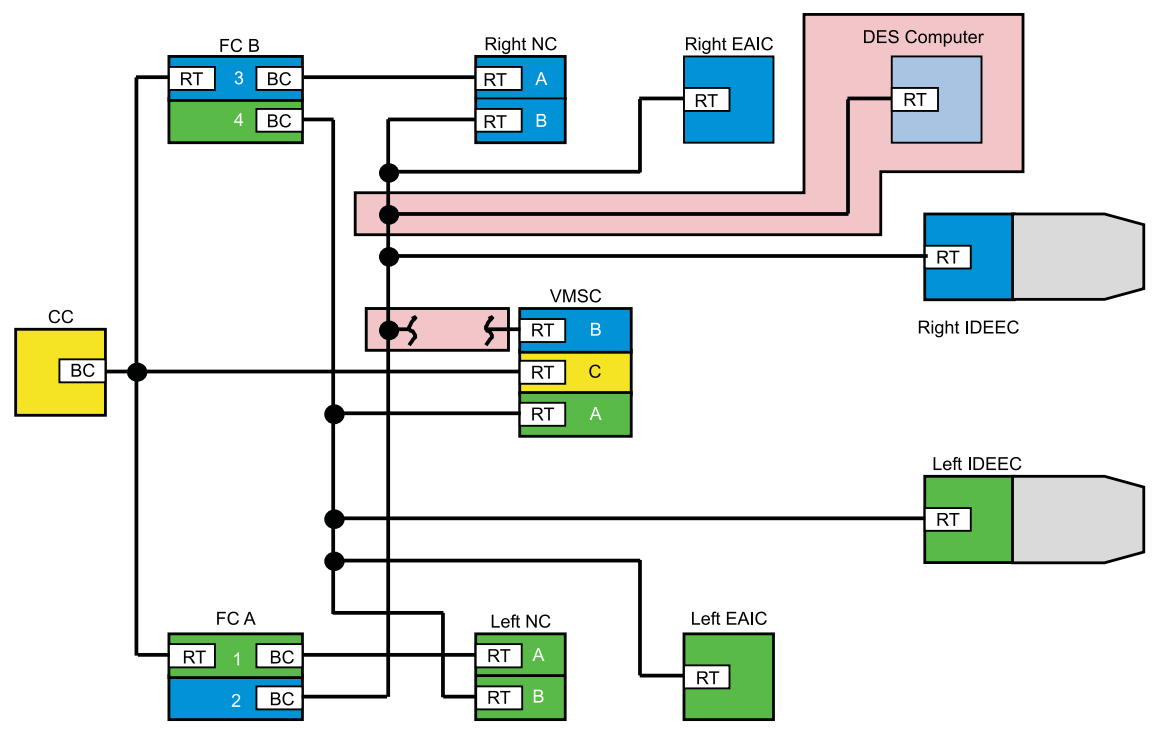

Figure 8. HISTEC Bus

\section{FLIGHT TEST RESULTS}

The HISTEC flight test instrumentation performed exceptionally well during the flight test. All highresponse pressure transducers were checked for drift during testing. This was accomplished through a preflight engine-off data point taken at the beginning of each day of testing. This information was then compared to an independent atmospheric pressure measurement, with the difference (psi) applied to the transducer for the remainder of the day. The difference, known as the ambient offset, was plotted versus test day and fit with a linear least squares curve fit. The slope of the linear fit is a measure of transducer drift. The slope was always small compared to the standard error of the data indicating that system uncertainty masked any transducer drift that may have occurred. Table 1 shows the slope and standard error (psi) for the transducers with the largest drift, least drift and the transducer that fell in the middle. In the table, transducers with a PTIGV header were the high-response total pressure type, located in the fan inlet guide vane strut while PSW20 was one of the high-response wall static transducers.

Each day, there was also a pressure calibration data point taken at 20,000 ft, $0.6 \mathrm{Mach}(20 \mathrm{~K} / 0.6)$, straight and level at full power. All total pressure transducers were repeatable to within 2.5 percent while all static pressure transducers were repeatable to within 5 percent.

Stall margin loss from HISTEC was compared to that calculated using ARP 1420 methodology for all specified audit points (Figure 9). ARP 1420 is the current industry standard and is used as the baseline for comparative purposes. There is no direct comparison 
Table 1. Summary of HISTEC flight Test Instrumentation Drift Analysis

\begin{tabular}{lccc}
\hline \multicolumn{1}{c}{ Transducer } & Average & Slope & $\begin{array}{c}\text { Standard } \\
\text { Deviation }\end{array}$ \\
\hline $\begin{array}{l}\text { PTIGV9-5 } \\
\text { (Max. slope) }\end{array}$ & 0.4533 & 0.3181 & 1.1492 \\
$\begin{array}{l}\text { PTIGV19-3 } \\
\text { (Min. slope) }\end{array}$ & -0.0728 & 0.0001 & 0.0128 \\
$\begin{array}{l}\text { PSW20 } \\
\text { (Median slope }\end{array}$ & 0.0065 & 0.0107 & 0.0497 \\
\hline
\end{tabular}

between ARP 1420 and the modal DES distortion indices, therefore, only the final SML numbers are compared.

In Figure 9, the SML difference shown is the percent difference between the DES estimate and the ARP1420 estimate. The maximum difference in SML estimates between the HISTEC DES algorithm and the ARP 1420 analysis is within the success criteria of 2.5 percent set prior to flight test. The DES SML estimates are slightly higher than ARP 1420 for all but the $5 \mathrm{~K} / 0.3$ case.

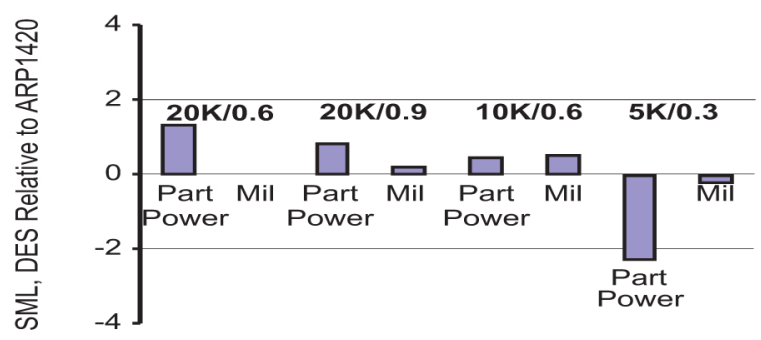

Figure 9. Comparison of Stall Margin Loss Estimates Between HISTEC DES and ARP 1420 for 1 -G Level Flight

For aircraft maneuvers, the DES estimates of stall margin also compare favorably with ARP 1420 methodology estimates. Figure 10 shows a comparison for various angles-of-attack up to $25 \mathrm{deg}$, at $20 \mathrm{~K} / 0.6$. These conditions were achieved by windup turns and Split-S maneuvers.

For qualitative comparison purposes, inlet total pressure surfaces were constructed for circumferential Modes 1 and 2 and radial Modes 1 and 3, using both the research instrumentation and DES pressure measurements. Typical surfaces, generated aft looking forward, are shown in Figure 11.

As seen in Figure 11, there is excellent agreement between the two surfaces. The relative distortion levels,

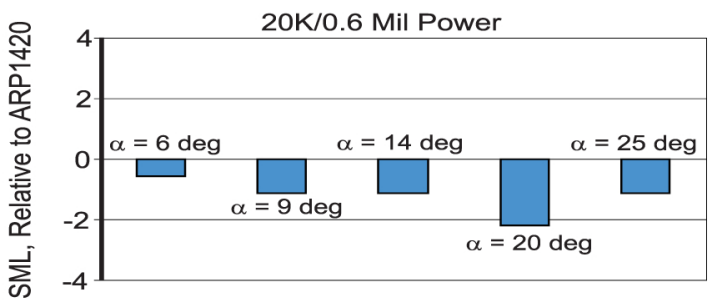

Figure 10. Stall Margin Loss Comparison at Various Angles-of-Attack

represented by the surface shading, are very similar. Figure 11a is at low airflow relative to the others and shows the effect of airflow on distortion. Notice that both radial and circumferential distortion are shown in the DES surface. The DES surface shows slightly more radial distortion than that generated using the research instrumentation. The extent of the circumferential distortion is less in the DES surface compared to the research surface. The circumferential distortion is rotated slightly in the DES surface relative to the research surface. This is due to the DES static pressure transducers being located in a slightly different axial plane than the research instrumentation.

Flight data analysis has confirmed that HISTEC can measure and compensate for inlet pressure distortion in flight using only static pressure measurements. Figure 12 illustrates HISTEC operation for an $\alpha$ sweep to 28 degrees. For this case, a simulated audit limit of 7 percent was incorporated into the SMC to force control action to downmatch the engine to accommodate high levels of inlet distortion. For the $\alpha$ sweep shown, the trim on fan stall pressure ratio is a result of measured inlet pressure distortion while engine stability is accommodated via the SMC for that distortion, illustrated by the lower engine pressure ratio commanded by HISTEC (lower right hand graphic in Figure 12).

\section{CONCLUSIONS}

Flight demonstration of a distortion-tolerant control system was successfully completed on the NASA ACTIVE F-15 aircraft. The predicted stall margin loss at specified flight conditions met the goal of being within 2.5 percent of predictions made using ARP 1420 analysis with research instrumentation. The stability management control downmatched the engine to accommodate the measured inlet distortion. Other issues that need to be addressed with this approach include determining if the HISTEC concept is airframe independent. Also, higher levels of distortion would be desirable to further challenge the approach. 
a) $20 \mathrm{~K} / 0.6 \mathrm{M}, \alpha=3 \mathrm{deg}, \beta=1 \mathrm{deg}$, Part Power Right Hand Engine, Aft Looking Forward DES Static Pressure Sensors

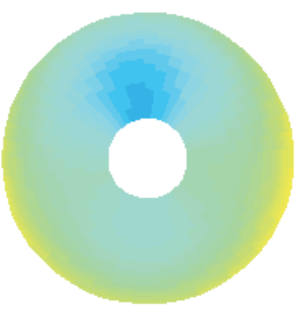

Research Total Pressure Sensors

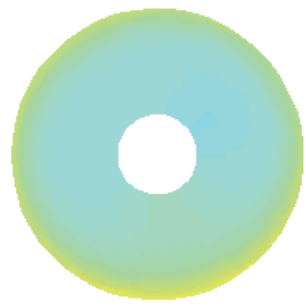

Normalized Total Pressure

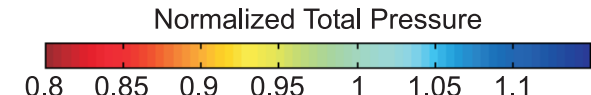

c) $20 \mathrm{~K} / 0.6 \mathrm{M}, \alpha=9 \mathrm{deg}, \beta=1 \mathrm{deg}$, Mil Power Right Hand Engine, Aft Looking Forward DES Static Pressure Sensors Research Total Pressure Sensors
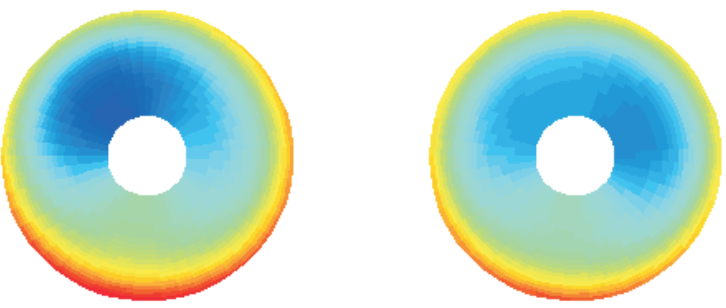

Normalized Total Pressure

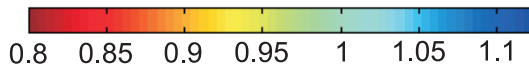

e) $20 \mathrm{~K} / 0.6 \mathrm{M}, \alpha=20 \mathrm{deg}, \beta=1 \mathrm{deg}$, Mil Power Right Hand Engine, Aft Looking Forward DES Static Pressure Sensors Research Total

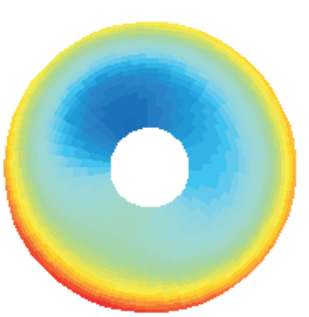
Pressure Sensors

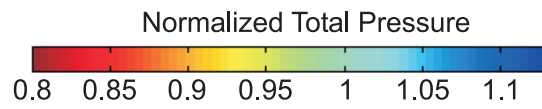

b) $20 \mathrm{~K} / 0.6 \mathrm{M}, \alpha=6 \mathrm{deg}, \beta=1 \mathrm{deg}$, Mil Power Right Hand Engine, Aft Looking Forward

DES Static

Pressure Sensors

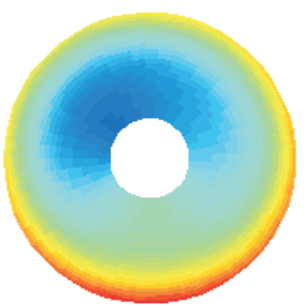

Normalized Total Pressure
Research Total Pressure Sensors $\begin{array}{lllllll}0.8 & 0.85 & 0.9 & 0.95 & 1 & 1.05 & 1.1\end{array}$

d) $20 \mathrm{~K} / 0.6 \mathrm{M}, \alpha=14 \mathrm{deg}, \beta=1 \mathrm{deg}$, Mil Power Right Hand Engine, Aft Looking Forward DES Static

Pressure Sensors

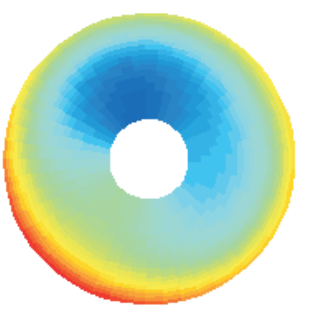

Research Total Pressure Sensors

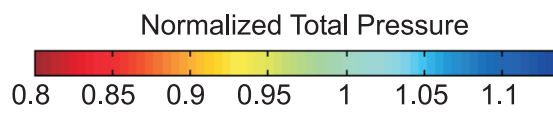

f) $20 \mathrm{~K} / 0.6 \mathrm{M}, \alpha=25 \mathrm{deg}, \beta=3 \mathrm{deg}$, Mil Power Right Hand Engine, Aft Looking Forward DES Static Pressure Sensors Research Total Pressure Sensors
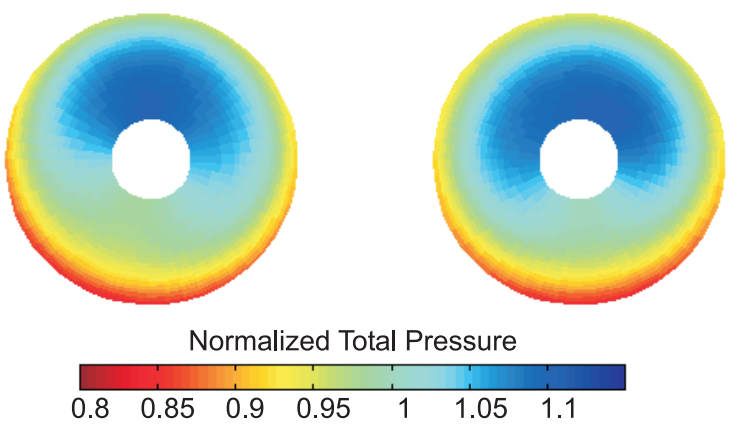

Figure 11. Comparison of ACTIVE F-15 Inlet Total Pressure Patterns Using Research Instrumentation and DES Pressure Measurements 

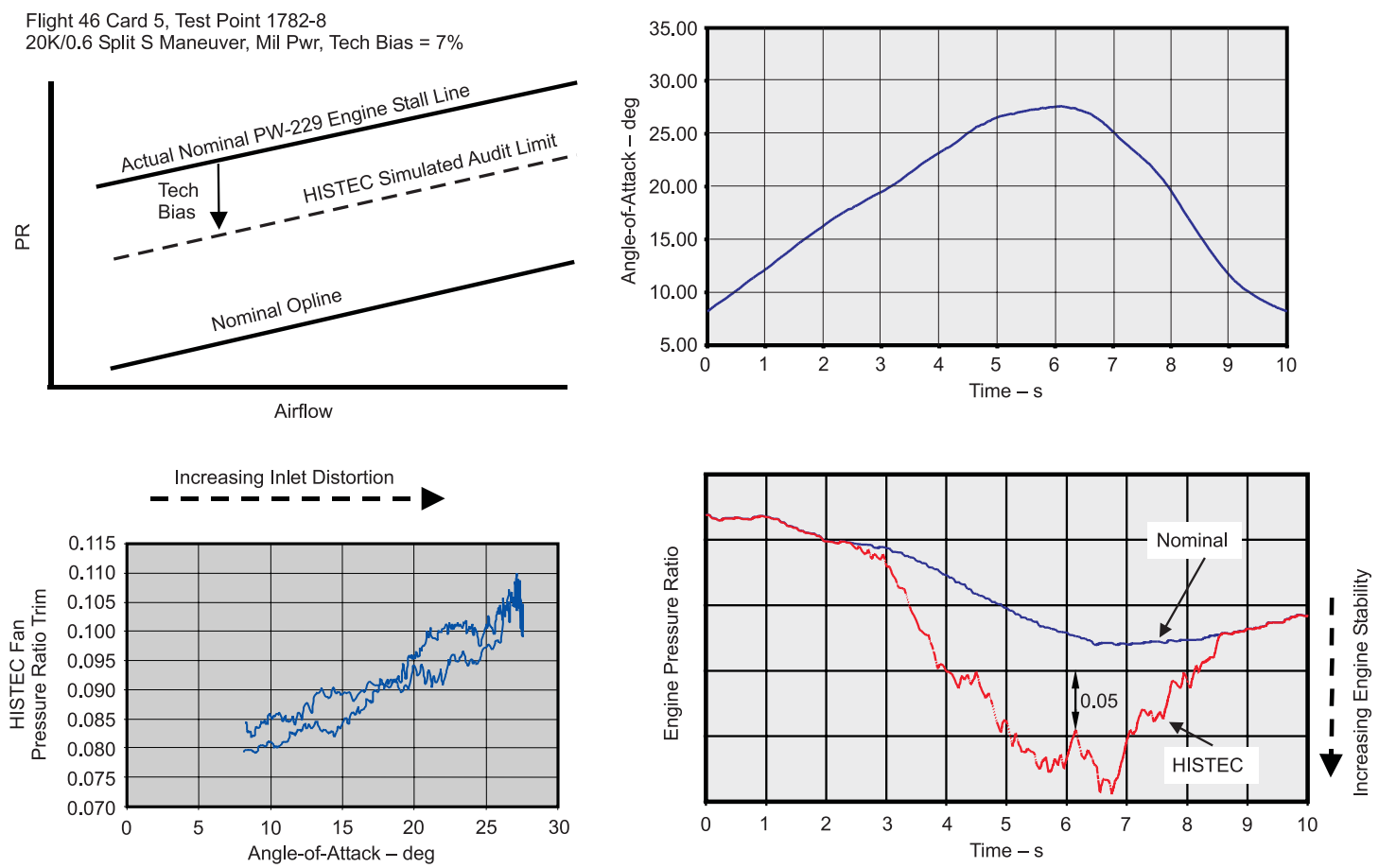

Figure 12. HISTEC Operation for Angle-of-Attack Sweep

\section{REFERENCES}

1. Southwick, Robert D., George W. Gallops, Louis J. Larkin, and Kurt J. Sobanski. High Stability Engine Control (HISTEC) Phase I: Algorithm Development, Volume I: Final Report and Appendix A, NASA CR 198399, September 1995.

2. Orme, J. S., J. C. DeLaat, R. D. Southwick, G. W. Gallops, and P. M Doane. Development and Testing of a High Stability Engine Control (HISTEC) System. Paper AIAA-98-3715, presented at the 34th AIAA/ASME/SAE/ASEE Joint Propulsion Conference and Exhibit, Cleveland, July 1998.

3. DeLaat, J. C., R. D. Southwick, G. W. Gallops, and J. S. Orme. The High Stability Engine Control (HISTEC) Program: Flight Demonstration Phase. Paper AIAA-98-3756, presented at the 34th AIAA/ ASME/SAE/ASEE Joint Propulsion Conference and Exhibit, Cleveland, July 1998.

4. U. S. Patent 074431 Gas Turbine Engine Control Based on Inlet Pressure Distortion. Issued September 1995, assigned to United Technologies Corporation.
5. Society of Automotive Engineers. Gas Turbine Engine Inlet Flow Distortion Guidelines, Aerospace Recommended Practice (ARP) 1420, 1978.

6. Society of Automotive Engineers. A Current Assessment of Planar Waves. Aerospace Resource Document (ARD) 50026, 1994.

7. Gong, Y., C. S. Tan, and K. A. Gordon. A Computational Model for Short Wavelength Stall Inception and Development in Multi-Stage Compressors. Paper 98-GT-476, presented at the International Gas Turbine and Aeroengine Congress and Exhibition, Stockholm, June 1998.

8. Longley, J. P., H. W. Shin, R. E. Plumley, P. D. Silkowski, I. J. Day, E. M. Greitzer, C. S. Tan, and D. C. Wisler. Effects of Rotating Inlet Distortion on Multistage Compressor Stability. ASME Journal of Turbomachinery 118, pp. 181-188, 1996.

9. DeLaat, John C., Robert D. Southwick, and George W. Gallops. High Stability Engine Control (HISTEC). Paper AIAA-96-2586, presented at the 32nd AIAA/ASME/SAE/ASEE Joint Propulsion Conference and Exhibit, Lake Buena Vista, July 1996. 
Public reporting burden for this collection of information is estimated to average 1 hour per response, including the time for reviewing instructions, searching existing data sources, gathering and maintaining the data needed, and completing and reviewing the collection of information. Send comments regarding this burden estimate or any other aspect of this collection of information, including suggestions for reducing this burden, to Washington Headquarters Services, Directorate for Information Operations and Reports, 1215 Jefferson Davis Highway, Suite 1204, Arlington, VA 22202-4302, and to the Office of Management and Budget, Paperwork Reduction Project (0704-0188), Washington, DC 20503. \begin{tabular}{|l|l|l}
\hline 1. AGENCY USE ONLY (Leave blank) & $\begin{array}{c}\text { 2. REPORT DATE } \\
\text { July } 1998\end{array}$ & $\begin{array}{r}\text { 3. REPORT TYPE AND DATES COVERED } \\
\text { Technical Memorandum }\end{array}$
\end{tabular}

4. TITLE AND SUBTITLE 5. FUNDING NUMBERS

High Stability Engine Control (HISTEC) Flight Test Results

6. AUTHOR(S)

WU-523-53-13-00

Robert D. Southwick, George W. Gallops, Laura J. Kerr, Robert P. Kielb, Mark G. Welsh, John C. DeLaat, and John S. Orme

\section{PERFORMING ORGANIZATION NAME(S) AND ADDRESS(ES)}

National Aeronautics and Space Administration

Lewis Research Center

Cleveland, Ohio 44135-3191

8. PERFORMING ORGANIZATION REPORT NUMBER

E-11255

\section{SPONSORING/MONITORING AGENCY NAME(S) AND ADDRESS(ES)}

National Aeronautics and Space Administration

Washington, DC 20546-0001

10. SPONSORING/MONITORING AGENCY REPORT NUMBER

NASA TM-1998-208481

AIAA-98-3757

\section{SUPPLEMENTARY NOTES}

Prepared for the 34th Joint Propulsion Conference cosponsored by AIAA, ASME, SAE, and ASEE, Cleveland, Ohio, July 12-15, 1998. R.D. Southwick, G.W. Gallops, L.J. Kerr, R.P. Kielb, and M.G. Welsh, Pratt \& Whitney, West Palm Beach, Florida 33410-9600; J.C. DeLaat, NASA Lewis Research Center; J.S. Orme, NASA Dryden Flight Research Center, Edwards, California. Responsible person, J.C. DeLaat, organization code 5530, (216) 433-3744.

12a. DISTRIBUTION/AVAILABILITY STATEMENT

12b. DISTRIBUTION CODE

Unclassified - Unlimited

Subject Category: 07

Distribution: Nonstandard

This publication is available from the NASA Center for AeroSpace Information, (301) 621-0390.

\section{ABSTRACT (Maximum 200 words)}

The High Stability Engine Control (HISTEC) Program, managed and funded by the NASA Lewis Research Center, is a cooperative effort between NASA and Pratt \& Whitney (P\&W). The program objective is to develop and flight demonstrate an advanced high stability integrated engine control system that uses real-time, measurement-based estimation of inlet pressure distortion to enhance engine stability. Flight testing was performed using the NASA Advanced Controls Technologies for Integrated Vehicles (ACTIVE) F-15 aircraft at the NASA Dryden Flight Research Center. The flight test configuration, details of the research objectives, and the flight test matrix to achieve those objectives are presented. Flight test results are discussed that show the design approach can accurately estimate distortion and perform real-time control actions for engine accommodation.

\section{SUBJECT TERMS}

Aircraft engines; Engine control; Flow distortion; Stability; Augmentation

\begin{tabular}{|c|c|c|}
\hline $\begin{array}{c}\text { 17. SECURITY CLASSIFICATION } \\
\text { OF REPORT } \\
\text { Unclassified }\end{array}$ & $\begin{array}{c}\text { 18. SECURITY CLASSIFICATION } \\
\text { OF THIS PAGE } \\
\text { Unclassified }\end{array}$ & $\begin{array}{c}\text { 19. SECURITY CLASSIFICATION } \\
\text { OF ABSTRACT } \\
\text { Unclassified }\end{array}$ \\
\hline
\end{tabular}

